\title{
Performance of setaria in the northern North Island
}

\section{Abstract}

Setaria sphacelata is a perennial $\mathrm{C}_{4}$ grass that has high potential summer yield, but its persistence and cool-season production are poor. An experiment investigated whether a winter oats cover crop could negate these poor traits. While oversowing oats into established setaria increased total winter-spring herbage production, the use of a cover crop reduced setaria persistence despite minimum soil temperatures being $1.5^{\circ} \mathrm{C}$ higher. Starch and soluble sugar levels in three different leaf and stem fractions of setaria were low and showed little seasonal variation. S. sphacelata and $S$. neglecta plants that had survived previous evaluations were transplanted into a field nursery and screened for a further 3 years. From this nursery, blocks of four phenotypically different lines were then established and their performance (herbage production and quality) was assessed for 2 years. Mean annual yields of the more productive blocks were $12.5 \mathrm{t} / \mathrm{ha}, 60 \%$ of this occurring during January-March. Herbage quality was assessed as being low-medium, leaf in vitro digestibilities and crude protein being $70 \%$ and $12 \%$ respectively. Within this "persistent" population, soluble sugars in the basal fractions of the plant appear important in assisting cool-season persistence. The place of a perennial $\mathrm{C}_{4}$ grass such as setaria in farm systems was investigated using the computer model Stockpol. A small specialist block of setaria may have merit for feeding breeding stock where there is a need to miriimise the risk of drought in northern zones of New Zealand.

Keywords: carbohydrates, cover crop, forage quality, persistence, Setariaspp.

\section{Introduction}

Low pasture growth from January to April regularly limits animal production in New Zealand's pastoral systems. The species sown in pastures are generally of temperate origin and a combination of low soil moisture and high temperatures during late summer-early autumn restricts growth. Annual summer crops can be sown to cover this deficit, but the cost of establishment can often negate the benefits.

In warmer areas of New Zealand, $\mathrm{C}_{4}$ pathway grasses such as paspalum (Paspalum dilatatum Poir) and kikuyu (Pennisetum clandestinum) contribute significantly to warm-season pasture production (Lambert 1967); however feed quality of these species is often poor. Setaria (Setaria sphacelata) is another perennial $\mathrm{C}_{4}$ grass, which can produce in excess of $20 \mathrm{t}$ DM/ha annually (Taylor et al. 1976; Sithamparanathan 1979). However, poor persistence, low feed quality, low cool-season production and specific management requirements have meant that there has been little development of this species in New Zealand.

A long-term series of experiments was conducted at AgResearch Whatawhata Research Centre in the North Island of New Zealand (latitude $37^{\circ} \mathrm{S}$ ) to investigate aspects of setaria persistence and production. The experimental region is classified as warm-temperate with a mean annual air temperature of $13^{\circ} \mathrm{C}, 42$ ground frosts below $-1{ }^{\circ} \mathrm{C}, 16$ ground frosts below $-3{ }^{\circ} \mathrm{C}$ and rainfall of $1600 \mathrm{~mm}$.

This paper reports on results from two experiments designed to test the ability of a winter cover crop and plant screening to improve setaria persistence.

\section{Methods}

\section{Experiment 1 - Oats cover crop}

The objective of this experiment was to assess the impact of a winter oats cover crop on cool-season herbage production and setaria persistence. In addition, the experiment provided an opportunity to monitor levels of non-structural carbohydrates throughout the year and to determine whether carbohydrate reserves are important in cool-season persistence.

A block of $S$. sphacelata (cv. Narok) was sown in early November, 1979 and divided into 8 plots of 0.011 ha each. The site was north-west facing with an 8 " slope. Two treatments (with or without oats) were randomly allocated within 4 block replicates. On the appropriate plots oats were broadcast at $160 \mathrm{~kg} / \mathrm{ha}$ in late March 1980 and trampled with sheep to ensure ground contact. After 22 days, oat seedling densities averaged $308 / \mathrm{m}^{2}$. Urea was applied at $50 \mathrm{~kg} \mathrm{~N} / \mathrm{ha}$ on 24 April, 12 June and 20 November 1980. Plots were 
grazed with cattle on 28 May, 7 October and 12 December 1980. Net herbage accumulation was determined by differences. in post and pre-grazing herbage mass which was estimated by cuts to ground level. A high post-grazing residual was left after the May grazing $(\approx 3.0 \mathrm{t} \mathrm{DM} / \mathrm{ha})$ to enhance winter survival of setaria plants. Setaria tiller densities were determined in November 1980.

Factors that may have determined persistence were measured by the following methods. Temperature probes were placed in the $0-5 \mathrm{~mm}$ soil depth zone and, between 10 July and 20 July, temperatures were measured in both treatments adjacent to setaria crowns. Bare ground and shaded air temperatures (I $00 \mathrm{~mm}$ above ground) were also measured. On 7 occasions throughout 1980, setaria plants were sampled from both treatments for the determination of non-structural carbohydrate (NSC) levels. Plants were broken into 3 fractions, viz:

\section{I. leaf}

2. leaf sheath (excluding the basal $30 \mathrm{~mm}$ of sheath)

3. crown (lower $30 \mathrm{~mm}$ of sheath plus basal stem)

Ground plant tissue $(200 \mathrm{mg})$ were extracted to AOAC (1975) recommendations using $80 \%$ ethanol and total sugars were determined by the method of Bailey (1958). The residue was boiled in water and starch was determined as glucose by addition of amyloglucosidase and then glucose oxidase (AOAC 1975).

\section{Nursery plantings}

In November 1980, setaria plants that survived the cover crop experiment were sampled and transplanted into a field nursery that was adjacent to the experiment 1 site, as were surviving plants of S. neglecta (various C.P.I. accessions) that had been planted in 1979 . Climate records showed these years (1981-1983) as being near the long-term average for frost numbers (Table 1). Between 1980-1983, this nursery area was mob grazed with sheep and cattle.

\section{Experiment 2 - Herbage production and quality of persistent lines}

This experiment sought to quantify the production and herbage quality of a mixed Setaria spp. population made from plants that had survived 3-5 years of field screening at Whatawhata. These results would then provide some basis for assessing the likely role of setaria as a forage source within a farm systems context.
In December 1983 plants within the nursery were classified into 4 phenotypic groupings, viz: fine leaf width, medium leaf width, coarse leaf width with erect habit, and coarse leaf width with prostrate habit. Tillers were transplanted into 4 adjacent blocks on the basis of these classes. In autumn 1984, the morphological features of these 4 classes were visually scored (Table 2).

Subterranean clover (Trifolium subterraneum $\boldsymbol{c v}$ Tallarook) and white clover (Trifolium repens $c v$ Grasslands Pitau) were broadcast sown between rows at the time of transplanting. The site was north facing with a slope of $20 \%$. Urea was applied at $50 \mathrm{~kg} \mathrm{~N} / \mathrm{ha}$ in November 1984. After a 12-month establishment phase, herbage yield was measured by cutting sample areas at a height of $100 \mathrm{~mm}$ from the base of the crown. Blocks were then grazed with sheep and cattle to $100 \mathrm{~mm}$. When required, blocks were mown after grazing to remove reproductive stem material. These yield cuts continued for 2 years (June 1984-June 1986).

Forty tillers were sampled at dawn from each block at 7 harvest dates during the second production year. Tillers were broken into 3 fractions, viz:

1. leaf (leaf lamina plus sheath above $30 \mathrm{~mm}$ from crown base).

2. crown sheath (basal $30 \mathrm{~mm}$ of leaf sheath).

3. stem (underground stem plus the lower $100 \mathrm{~mm}$ of reproductive stem).

These fractions were analysed for NSC as described for experiment 1, for total nitrogen (Gehrke et al. 1972) and in vitro digestibility.

Table 1 Number of ground and screen frosts

\begin{tabular}{ccc}
\hline & $\begin{array}{c}\text { Ground frosts } \\
\text { below }-1^{\circ} \mathrm{C}\end{array}$ & $\begin{array}{c}\text { Screen frosts } \\
\text { below } 0^{\circ} \mathrm{C}\end{array}$ \\
\hline 1979 & 19 & 7 \\
1980 & 37 & 9 \\
1981 & 44 & 6 \\
1982 & 62 & 21 \\
1983 & 45 & 14 \\
1984 & 48 & 12 \\
1985 & 39 & 8 \\
1986 & 44 & 14 \\
Mean $1952-1980$ & 39.2 & 10.9 \\
\hline
\end{tabular}

Table 2 Morphological features (mean of individual plant scores) of setariablocks.

\begin{tabular}{lccc}
\hline Block/Phenotype & Leaf width & Erectness & Heading \\
\hline Fine leaf & 1.21 & 4.04 & 3.10 \\
Medium leaf & 3.56 & 3.68 & 1.87 \\
Coarse leaf, erect & 4.00 & 4.79 & 1.14 \\
Coarse leaf, prostrate & 4.2 & 2.8 & 2.4 \\
Scoring Criteria & 1 = Fine leaved & 1 = Prostrate form & 0 = No seed-heads \\
& 5 = Coarse leaved & 5 = Erect form & $5=$ Many seed-heads \\
\hline
\end{tabular}




\section{Results and discussion}

\section{Experiment 1 -Winter oats cover crop}

\section{Net herbage accumulation andpersistence}

Total net herbage accumulation was $30 \%$ greater where the oats cover crop was used (Table 3), the greatest increase occurring during the June-September period. The presence of a cover crop did, however, reduce setaria growth, particularly in mid-late spring as new season growth began. This lower setaria production reflected poor survival under a cover crop regime, with setaria tiller densities of $15 / \mathrm{m}^{2}$ and $52 / \mathrm{m}^{2}$ on 6 November, for with and without oats treatments respectively.

Table 3 Net herbage accumulation for experiment $1(\mathrm{~kg}$ DM/ha).

\begin{tabular}{|c|c|c|c|c|c|}
\hline \multirow[b]{2}{*}{9 Nov-14 Jan } & \multicolumn{2}{|c|}{$\begin{array}{l}\text {-- No cover crop -- } \\
\text { Setaria Other sp. }\end{array}$} & \multicolumn{3}{|c|}{$\begin{array}{l}\text {.........Covercrop } \\
\text { Setaria Oats Other sp. }\end{array}$} \\
\hline & $\begin{array}{l}1700 \\
3200\end{array}$ & $\begin{array}{l}560 \\
870\end{array}$ & $\begin{array}{l}1630 \\
3350\end{array}$ & $\begin{array}{l}0 \\
0\end{array}$ & $\begin{array}{r}500 \\
1130\end{array}$ \\
\hline $\begin{array}{l}26 \text { Mar-28 May } \\
30 \text { May-7 Oct }\end{array}$ & $\begin{array}{l}1370 \\
-1010\end{array}$ & $\begin{array}{c}90 \\
610\end{array}$ & $\begin{array}{r}870 \\
-1630\end{array}$ & $\begin{array}{c}1010 \\
5690\end{array}$ & $\begin{array}{l}0 \\
0\end{array}$ \\
\hline 7 Oct- 12 Dec & 2250 & 510 & 850 & -1450 & 1100 \\
\hline Species total & 7510 & 2640 & 5070 & 5250 & 2730 \\
\hline $\begin{array}{l}\text { Treatment total } \\
\text { SED }\end{array}$ & & & & 13050 & \\
\hline
\end{tabular}

\section{Temperature}

Differences between treatments in ground temperatures were greatest on 17-18 July (Figure 1). Minimum temperatures adjacent to setaria crowns were only $1.5^{\circ} \mathrm{C}$ higher where the cover crop was used. Further, daily maxima were lower in the cover crop treatment. While the sowing of oats provided some small measure of insulation, the benefits did not outweigh the competitive impact of the cover crop on setaria density and growth.

Starch and soluble sugar levels

Starch levels in all three fractions were similar and remained at a constant, relatively low level throughout the season (Figure 2). The November sampling was an exception which cannot be explained. Paspalum, a $\mathbf{C}_{\mathbf{4}}$ grass that survives in this experimental environment, has starch levels within its rhizomes that increase from $1.3 \%$ of herbage dry weight in summer to $10 \%$ in autumn (Thorn et al. 1989). This build-up of reserves is assumed to enhance its ability to survive over winter. No similar build-up was displayed in any of the three setaria fractions.

Soluble sugars (Figure 2) were least in the leaf lamina fraction during the winter-spring period when the leaves were chlorotic. Sugar levels in the basal
Figure 1 Crown temperatures 17-18 July for setaria with oats (----), setaria only (---) and $100 \mathrm{~mm}$ air temperature $(-)$

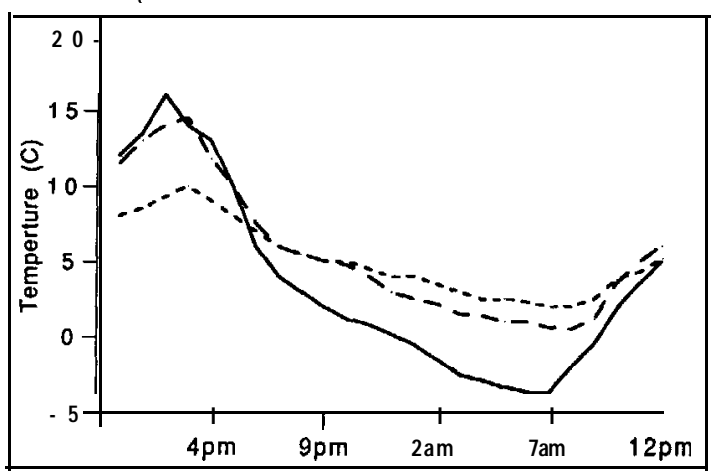

Figure 2 Starch levels and sugar levels ( $\%$ of dry weight) for leaf $\longrightarrow$, leaf sheath (---) and crown (---.-) (bars show SED).

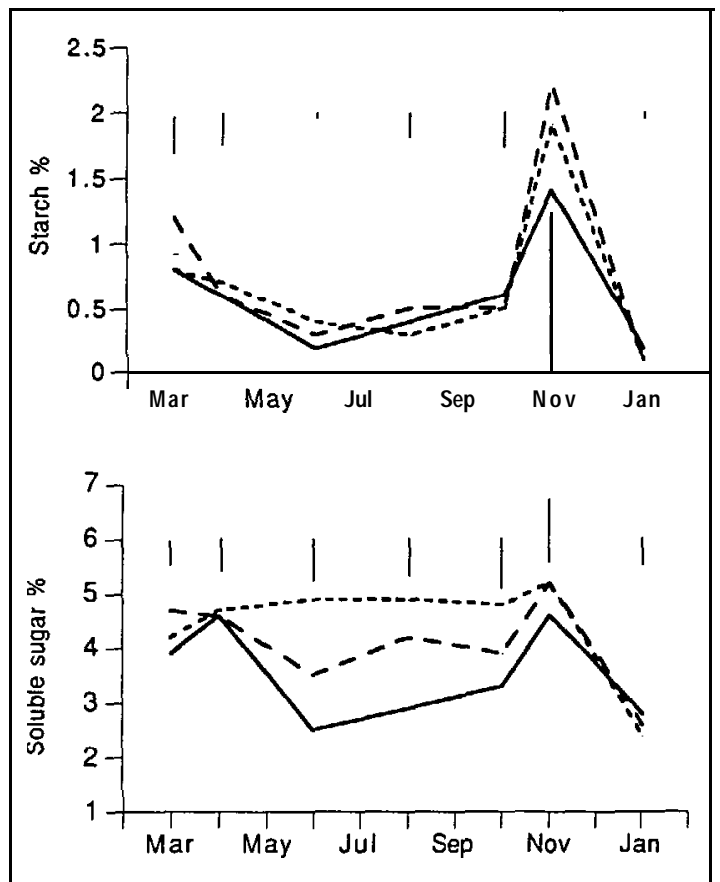

crown fractions were higher, but showed no seasonal pattern of accumulation or usage. There were no significant differences in soluble sugars between treatments. It can be concluded that setaria plants had to rely on current photosynthates to survive through winter-spring. Given the apparent importance of retaining choroplast integrity during cold temperatures, a nursery was established to screen for plants that would survive climatic conditions at the experimental site. 


\section{Experiment 2 -Production and quality of persistent lines}

\section{Herbage production}

Total herbage production was least for the fine-leaf phenotype in both years (mean $6.8 \mathrm{t} \mathrm{DM} / \mathrm{ha}$ ). The other three lines had similar annual yield performances which across the two years averaged $12.5 \mathrm{t} \mathrm{DM} / \mathrm{ha}$. These production levels were well below the $25 \mathrm{t} \mathrm{DM} / \mathrm{ha}$ yields in small-plot evaluations within this environment recorded by Sithamparanathan (1979). While the difference between experiments may highlight the dangers of extrapolating from small plots, it must be acknowledged that yields may have been greater in our experiment if more $\mathrm{N}$ had been applied. Although clovers were sown into the setaria blocks, their survival and production were negligible, apparently due to the vigorous, tall growth of setaria during summer-autumn.

Over the same two years, total annual production of improved ryegrass-white clover pastures grown on soils of similar slope and fertility averaged $12.7 \mathrm{tDM} / \mathrm{ha}$ (Gillingham et al. 1990). Whereas pasture production during January-March was $15 \%$ of the annual total, setaria achieved $60 \%$ of its annual production during the same period (Figure 3).

Figure 3 Interpolated growth patterns (mean of 2 years) for fine leaf $(----)$, medium leaf (----) coarse leaf/ erect (- ) and coarse leaf/prostrate (-).

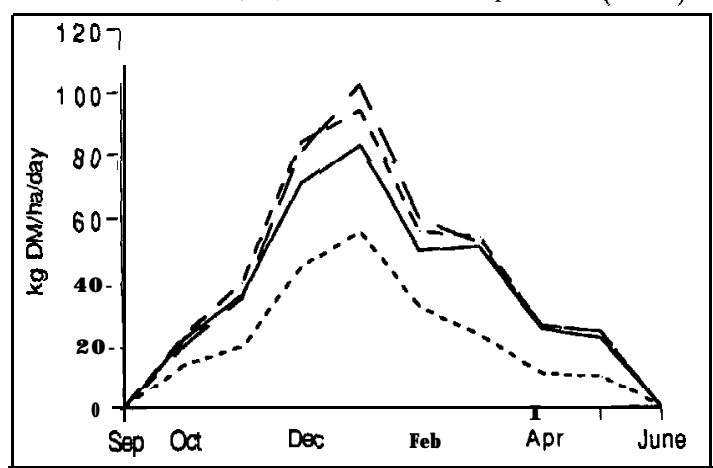

\section{Herbage quality}

While all three fractions were analysed for in vitro digestibilities and total herbage $\mathrm{N}$, only the results from the leaf fraction are relevant to herbage quality. This fraction included leaf lamina and all but the bottom 3 $\mathrm{cm}$ of leaf sheath. Leaf digestibility remained constant throughout the year (Figure 4). Digestibility levels of $70 \%$ would be similar to that of controlled leafy pasture of temperate species during summer (Waghom \& Barry 1987). While this might suggest that setaria leaf will provide an above-maintenance diet, it must be stressed that dried herbage samples were ground rather than minced and may therefore overstate actual quality (Waghom \& Caradus 1994).

Total $\mathrm{N}$ in the leaf fraction was generally consistent at around $1.8-2.0 \%$ of dry weight. The low value recorded in the October 1984 sampling was not repeated in the same month one year later. This level of total $\mathrm{N}$ would equate to approximately $12 \%$ crude protein, a level that is very close to minimum requirements for ruminant growth (Waghorn \& Barry 1987).

Figure 4 In vitro digestibility - $\longrightarrow$ ) and total nitrogen (-.-.) levels of setaria leaf component, mean of 4 phenotypic groups (bars show SED).

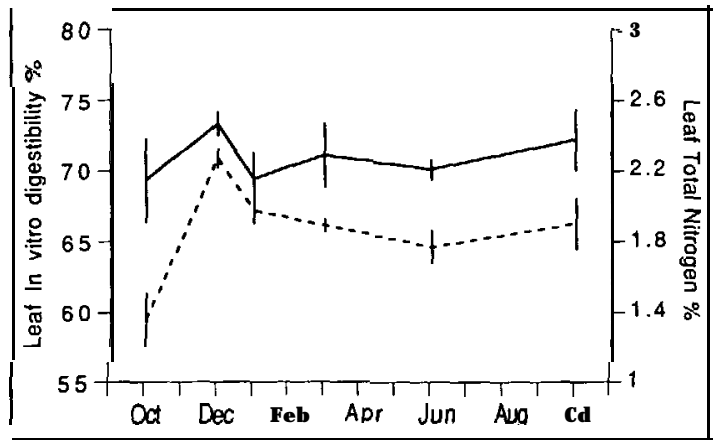

Soluble sugars and starch levels

Starch levels in all three fractions were consistently low throughout the year (Figure 5). These results reinforce those of experiment 1 and work by Davies \& Forde (1991), and indicates that starch is of little importance to the carbon economy of setaria.

In contrast to the results of experiment 1 , soluble sugars displayed a marked seasonal pattern and during winter-spring high levels were recorded in basal stem and sheath fractions (Figure 5). Levels of IO-15\% of dry weight were higher than those reported for Narok stems by Davies \& Forde (1991). These high levels were measured in a mixed population of $S$. sphacelata and $S$. neglecta plants that had demonstrated persistence at Whatawhata. Current soluble sugar status in basal fractions of setaria therefore appear to be important to its cool-season survival.

\section{Application of setaria in farm systems}

Perennial setaria species can be considered as a lowmedium quality forage source that could augment pastures in summer-dry, warmer regions of New Zealand. They could minimise risk in drought-prone areas.

The possible role of setaria was assessed in a Northland farm system using the computer model 
Figure 5 Starch levels and sugar levels (\% of dry weight) for 1 e a f (-), crown sheath (----) and stem (---) (bars show SED).

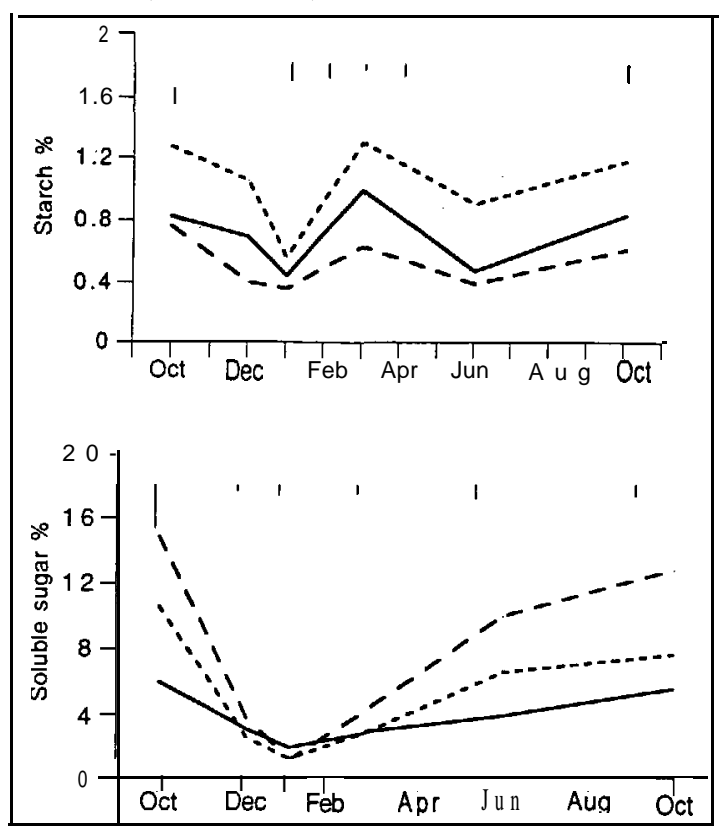

Stockpol (Marshall et al. 1991). The simulated model farm had a sheep:cattle ratio of 40:60, the cattle being Friesian bulls bought in at 3 months and sold at 20 months. Setaria herbage growth rates were interpolated on a monthly basis from the yield cuts of experiment 2 (Figure 3) and forage quality was judged as medium. The mean of 3 years' (1989-92) pasture growth rates on a Northland farm (Webby \& Sheath 1991) were also used in the analysis. Three scenarios were tested, viz. no setaria, $10 \%$ of farm area in setaria and $30 \%$ in setaria.

The introduction of $10 \%$ of farm area in setaria reduced total pasture supply slightly during winter and spring, but nearly doubled supply during January-March (Figure 6). The 30\% scenario reduced winter and spring supply significantly, but nearly tripled summer supply. Using the described stock policy, stocking rates could be increased by $22 \%$ and $25 \%$ for the $10 \%$ and $30 \%$ setaria scenarios respectively. Alternatively, the addition of such a perennial summer-growing species would sustain breeding stock liveweights during and following difficult dry periods and thereby reduce competition for forage with younger, growing livestock. Ideally this would be breeding cows, as experience has shown that sheep grazing alone at Whatawhata has not adequately controlled reproductive stem growth of setaria.

If setaria is to have a role, it will be on the basis of being a small, specialist block on the farm. It is unlikely
Figure 6 Simulated farm pasture supply patterns for no setaria

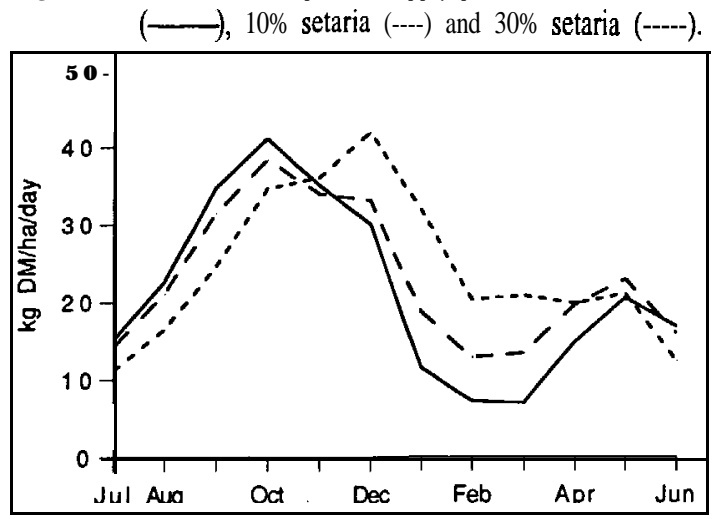

to be compatible with temperate grasses, but investigation into successful legume comparisons would benefit forage quality. Since the end of experiment 2, the setaria blocks have received a further 9 years of sheep and cattle grazing as per normal farm practice. Surviving plants are an important resource and have recently been sampled for further study and possible development in Northland.

\section{ACKNOWLEDGEMENTS}

Thanks to Rex Webby for assistance in evaluating possible setaria applications.

\section{REFERENCES}

AOAC. 1975. Official methods of analysis of the association of Official Analytical Chemists (12th Edition). Horwitz, W. Ed., Washington. Association of Official Analytical Chemists.

Bailey, R.W. 1958. Reaction ofpentoses with anthrone. Biochemical journal 68: 669-672.

Davies, L.J.; Forde, B.J. 199 1. Comparative responses of three sub tropical grasses to combined frost and prolonged chilling treatments simulating a New Zealand winter. New Zealandjournal of agricultural research 34: 249-256.

Gehrke, C.W.; Wall, L.L. 1972. Preliminary report on the Gehrke-Wall automated nitrogen method for feeds. Technicon International Congress 7: 25-32.

Gillingham, A.G.; Richardson, S.; Power, I.L.; Riley, J. 1990. Long term effects of withholding phosphate application on North Island hill country: Whatawhata Research Centre. Proceedings of the New Zealand Grassland Association 51: 1 I-16.

Lambert, J.P. 1967. Pasture species for Northland. Proceedings of the New Zealand Grassland Association 29: 78-87. 
Marshall, P.R.; McCall, D.G.; Johns, K.L. 1991. Stockpol: A decision support model for livestock farms. Proceedings of the New Zealand Grassland Association 53: 137-140.

Sithamparanathan, J. 1979. Seasonal growth patterns of herbage species on high rainfall hill country in northern North Island. New Zealand journal of experimental agriculture 7: 163-167.

Taylor, A.O.; Rolley, J.A.; Hunt, B.J. 1976. Potential of new summer grasses in Northland. New Zealand journal of agricultural research 19: 477-48 1.

Thorn, E.R.; Sheath, G.W.; Bryant, A.M. 1989. Seasonal variations in total nonstructural carbohydrate and major element levels in perennial ryegrass and paspalum in a mixed pasture. New Zealand journal of agricultural research 32: 157-1 65.

Waghom, G.C.; Barry, T.N. 1987. Pastures as a nutrient source. In Livestock feeding on pastures. New Zealand Society of Animal Production, Occ Public 10: 21-37.

Waghom, G.C.; Caradus, J.R. 1994. Screening for white clover cultivars for improved nutritive value development of a method. Proceedings of the New Zealand Grassland Association 56: 49-54.

Webby, R.W.; Sheath, G.W. 1991. Group monitoring a basis for decision making and technology transfer on sheep and beef farms. Proceedings of the New Zealand Grassland Association 53: 13-16. 